AWEJ for Translation \& Literary Studies, Volume3, Number3. August 2019

DOI: http://dx.doi.org/10.24093/awejtls/vol3no3.5

Pp. 68-81

\title{
On Translating Arabic Verbal Emphasis into English
}

\author{
Haitham (Mohd Khair) Ahmad ALYousef \\ Translation for professional department, School of Languages, Literacies and \\ Translation, Universiti Sains Malaysia \\ Penang, Malaysia \\ Tengku Sepora Tengku Mahadi \\ Translation for professional department, School of Languages, Literacies and \\ Translation, Universiti Sains Malaysia \\ Penang, Malaysia
}

\begin{abstract}
The translators constitute facing a challenge in the translation of Arabic verbal emphasis structure. Therefore, this study investigates the translation of Arabic verbal emphasis category and its subcategories into English from semantic and pragmatic perspectives. It draws upon an examination of several translations of these emphatic devices and structures into English. Specifically, it draws upon the translations of Naguib Mahfouz's novels The Thief and the Dogs (1961), Children of Gebalawi (1988) and the Harafish (2013) and Ghassan Kanafani's short stories Palestine's Children (2000). The study highlights the erroneous strategies adopted by the translators of these literary works and suggests more suitable alternative translations. As a result of several mismatches between Arabic and English leads to such errors. This study attempts to handle a gape in literature and help translators to overcome the obstacles they may face in rendering such Arabic structures in English. The article concludes that translating Arabic verbal emphatic structure into English would be affected by the syntactic, semantic and pragmatic symmetries and asymmetries between the two languages.
\end{abstract}

Keywords: Arabic verbal emphasis, repetition, translation

Cites as: ALYousef, H. A., \& Mahadi, T. S. T. (2019). On Translating Arabic Verbal Emphasis into English. Arab World English Journal for Translation \& Literary Studies, 3 (3) 68-81.

DOI: http://dx.doi.org/10.24093/awejtls/vol3no3.5 


\section{Introduction}

The translator has to concentrate on the message s/he transfers; since the core of translation is to transfer a text with its connotations and denotations from a source language (SL) into a target language (TL). Furthermore, translators must be faithful and sensitive to the semantic meanings of the source language text (SLT) i.e., the different meanings represented in the content of the message is called "the expressive meaning" related to "the speaker's feelings or attitudes" (Baker, 2018, p.13). Naturally, different users of a language can express their feelings and attitudes differently depending on a variety of syntactic devices which are available in that language. Users of language resort to language devices as emphatic devices which are intended to highlight primarily verbal emphasis type.

The present study examines the translation of Arabic verbal constructions into English, and it also addresses the effectiveness and contributions of the strategies that translators have adopted to convey the variable emphatic structures.

Quirk and Greenbaum assert that emphasis refers to the additional stress given to a sentence or part of it indicate prominence or importance in the utterance. It is generally used to highlight one or more of the sentence components to draw the addressee's attention to its importance relative to other constituents. Emphasis can be expressed by either stressing a particular element or using certain structural forms such as the emphatic pronoun and other particular syntactic structures (1973, p.312). Therefore, an emphatic structure is a syntactic technique used to highlight a certain form or part of a sentence for a particular pragmatic purpose. Emphasis structures, in both English and Arabic, have pragmatic functions (emphasis, focus, and theme prominence), and there are different ways to express such functions in the two languages.

\section{Emphasis in Arabic}

Emphasis is an ongoing process that restricts its follower by the direction of its report to raise the doubts which attach the mind of the listener. By emphasis, the speaker bases his speed in the attention of the listener in the course of the sentence systems (Albayati, 2003, p.260). Many different devices can express emphasis in Arabic. There two main categories of emphasis in Arabic (a) verbal and (b) meaning. This study confines to Arabic verbal emphasis category and its subcategory.

\section{Verbal Emphasis}

Repetition is the most common form of verbal emphasis. It is, in essence, a stylistic technique used to achieve specific pragmatic purposes such as reinforcement, explanation, concentration, illustration, drawing attention, and threat. Repetition is considered the most important and most proper strategy by Arab writers and speakers when trying to draw the attention of their addressees to the focal point of the discourse. Shunnaq (1989), for example, calls repetition indicating emphasis "emphatic repetition." Thus, emphatic repetition in Arabic discourse can take many forms. Repeating the same item or the item with its synonymous as in noun, verb, particle, sentence, phrase, clause, pronouns (attached and independent) adjective and adverb can achieve 
Arabic verbal emphasis. The researchers explain this kind of emphasis in detail in the findings and discussions section below.

\section{Meaning Emphasis}

Al-Gharanawi (2005) considers it to refine the meaning, without pronouncing it, by some words which are established for that such as nafis (نفس), ain (كين), kela (كلا), kelta (كلا), jamei' (جميع), a'ama (عامة), kul (كل) (p.279).

\section{Emphasis in English}

Mcarthur (1992) defines emphasis as a use of language to mark importance or significance through either intensity of expression or linguistic features such as stress and intonation. Means can achieve the emphasis in general that draw attention to a syllable, word, phrase, idea, event or social situation such as the increase of intensity and volume on of once when someone says: Do it once! (p.348). Celce-Murcia and Larson-Freeman (1983) point out that emphatic structures function overlaps with other structures such as exclamation and intensification. Besides, since the emphasis is mostly a semantic notion, it is likely to be signaled in many ways, including stress and intonation, choice of words, selection of grammatical patterns (p.408).

Arabic has its own syntactic devices of emphasis, so does English. Some of the emphatic tools available in English correspond to those of Arabic, while others do not.

\section{Ways of adding emphasis \\ The auxiliary verb}

One can add emphasis to a sentence by stressing the auxiliary verb or the be verb such as "I will write you a letter as soon as I arrive." In sentences where there is no auxiliary or be verbs, add do and stress it for emphasis such as "I do believe in miracles."

\section{Emphatic do}

Frodeson and Eyring (2000, p.402) indicate that emphatically do add emphasis to a whole sentence such as "You really do have a good thesis." It adds emphasis to an imperative. This use of emphatic do softens a command and shows polite encouragement such as "Do come in!." It contradicts a negative statement, and it is widespread in arguments such as "A: you didn't lock the door. B: you're wrong. I did lock it." It adds emphasis to a verb used in connection with an adverb of frequency such as never, seldom, rarely, often or always.

\section{Adverbs}

Gleason (1966) considers that some adverbs called "emphatic adverb" or "proverb adverb" used to add some kind of general emphasis to the sentence or to express some kind of reservation. They include some words as usual, certainly. For example: I certainly will go.

\section{Previous Studies}

Hassan (2015) examines the translation of verb repetition from Arabic into English, where it is mostly avoided. The repetition of a verb in Arabic indicates to an assertion, a specific situation, or a reminder of a previous event. Hassan works on translation media and literary texts; he 
concludes that the repetition of the Arabic verb is best deleted in English. Fathi (2004) examines repetition as a method of emphasis or reinforcement to speech in both languages i.e. Arabic and English. Repetition is used in different fields to pay the attention of a listener or reader. The study shows this phenomenon through the differences and similarities between the structures in Arabic and English. Mohammed (2013) considers emphasis in Arabic and its particles ways to emphasize the speech in Qur'an. The study shows ways of emphasizing particles in Arabic and indicates to some challenges that a translator may face when translating Qur'anic texts. It concludes that rendering of emphatic verses is not emphatic as the original. AlAubaidi (2013) considers the rhetorical function of repetition of sentences. It concludes that different methods of repetition indicate to different functions as assertion and the effects which emphasis adds to the sentence.

Most Arab grammarians agree that emphatic structures are syntactic techniques applied to focus on particular linguistic units to express a specific pragmatic function (Nahr, 2004 ; Maghalisah, 1997). Emphatic structures are known in classical and modern standard Arabic as verbal emphasis (al-tawkid al-llafthi) and meaning emphasis (al-tawkid al-ma'nawi). Most classical Arab grammarians consider that verbal emphasis happens only when the same item is repeated twice or more in sequence, and nothing separates it from the preceding one i.e., lexical repetition has only one form that is a repetition of the same item or literal repetition. Some modern Arab grammarians such as Deeb (1984), Nahr (2004) and Maghalisah (1997) insist that emphatic repetition also happens when an item is paraphrased by another synonym, and the repeated item can be separated by particular particles. Deeb (1984) considers some of the lexical emphasis functions such as reminding, warning, threatening, or calling attention to some feelings like sadness and happiness.

Alhrout (1983) examines Arabic emphatic structures on the semantic and syntactic levels. He mentions three primary strategies to express emphasis in Arabic discourse: (a) emphasis by the pronoun of separation, (b) emphasis by particular particles and (c) emphasis by additional particles. He concludes that emphasis can be expressed in different ways other than lexical devices.

Johnston (1991) investigates repetition as an emphatic style in mot cases in Arabic discourse and regards it as a persuasive device. She discusses two kinds of repetition at the morphological level: (a) repetition of patterns and (b) repetition of roots as in the cognate accusative. She concludes that repetition in English is a deviation from the norm, while in Arabic, it is not ornamental because it affects the structure of Arabic discourse. Farghal (1993) conducts a study on the translation of Arabic cognate accusatives into English. He states three major goals for using Arabic cognate accusative as follows: (a) to evaluate the action of the preceding verb, (b) to show the number of actions expressed by the verb, (c) to show the quality of the action expressed by the verb. Farghal concludes that Arabic and English include such symmetries as in sing a song and asymmetries regarding the cognate accusatives, so it would not be easy to translate them straightforwardly. The translator would have to employ different kinds of equivalence. The translators may opt for both formal and functional equivalences in the case of symmetries. Functional equivalence is due to the absence of one-to-one correspondence in the case of asymmetries.

Arab World English Journal for Translation \& Literary Studies 


\section{The Study}

This research is a qualitative descriptive study investigates the translation of Arabic verbal emphasis from semantic and pragmatic perspectives. The data of this research stems from the translation of three novels of Naguib Mahfouz (Children of Gebalawi, The Thief and the Dogs and the Harafish) and short stories of Ghassan Kanafani (Palestine's Children. The researchers choose 36 examples purposefully from the novels and short stories. They encompass the Arabic verbal emphasis structure, and they are classified into certain categories and subcategories. They are analyzed alongside their translations in English. To achieve the purpose of this study, appropriate and representative data were collected from the novels and short stories to exemplify and illustrate the translation of verbal emphatic structures and devices. The analysis of the collected data is comparative between Arabic and English texts to shed light on the strategies adopted by the translators and check whether they serve the same level of emphasis that source language texts suggest. The researchers collect Several English emphatic examples, and they comprise the corpora for the classifications of verbal emphasis. There are illustrative examples of each category are chosen purposefully from the novels and short stories and discussed. Finally, the researchers attempt to suggest the reasons for the erroneous translation in the discussion. Then they propose better translations of the source language as well as the strategies employed by the translators.

\section{Findings and Discussions}

The findings of the present study relate to Arabic verbal emphasis and its categories and the strategies of the novels and short stories translators. The focus of discussion is on the erroneous translation where the translators have failed to render quite adequately in English the clauses that include Arabic verbal emphatic structures. Therefore, better translations are proposed.

\section{Repetition of the same item}

One of the most essential linguistic styles in Arabic is repeating the same item as a noun, a verb, a pronoun, an adverb, a particle, a sentence, a phrase or a clause for the sake of emphasis (Deeb, 1984; Johnston, 1991). Shunnaq (1993) suggests that verbal repeition should be translated literally. Thus, the translator would be able to maintain its significant function in the SLT. Because of the fact that using Arabic verbal emphasis for specific purposes, most emphasis, so paraphrasing is not successful traslation strategy in rendering it. Thus it would affect the original pragmatic meaning.

\subsection{Noun Repetition}

The speaker usually uses this kind of emphasis to praise, warn, assert an exact idea to reinforce an idea in the text, and delete any doubts. It is evident in the following four examples that the speaker tries to praise the listener as in example (1), assert an exact idea to eliminate any doubts for the listener as in (2, $3 \& 4)$ and warn the listener as in (5). The translator in examples (1\&2) opts the functional meaning by using the repeated word in SLT once which fails to express praise in (1) and emphasize the meaning in (2) besides the emphatic function. It would be better if the translation is as follow: 
Amazing! Amazing! As handsome as your grandpa (1). And Cleanness. . cleanness (2). The translator does the same in examples (3), but by using the paraphrasing strategy, which fails to express the emphasis. The translation would be better if it is as follows:

If he had died, the fault would have been your fault.

To express a strong warning in (6), it is better to translate as follow: Be careful, be careful of violence that leads to feud. Thus, it is better to use literal translation in the examples to express the function of the sentences as in example (7).

: بديع بديع، ما اشبهك بجدك! (او لاد حارتنا، ص219)(1) مثال :

TT: Amazing! As handsome as Gebelawi! (Children of Gebelawi, p.141)

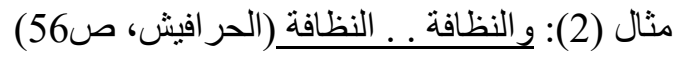

TT: And Hygiene! Always remember to take precautions. (The Harafish, p.34)

مثال(3): لو مات لكان الذنب ذنبك. (ابو الحسن يقوص على سيارة انكليزية،صا64)

TT: If he had died, it would have been your fault. (Abu Al-Hassan ambushes an English car, p.80)

مثال(4): اللمسة كافية لتحقيق النصر و الحذر الحذر من العنف لا يورث الا الضغينة. (الحر افيش، ص97)

TT: A touch is enough to decide the winner, Avoid violence at all costs. It only causes ill feeling. (The Harafish, p.67)(

: تصور بادئ الامر ان مهمة القائد هي أن يدور على المقاتلين واحدا واحدا ويرشدهم الى ما يتوجب فعله. (الصغير (5) مثال

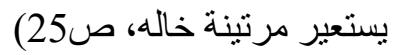

TT: First of all, he imagined that the importance of the leader must be to go around to all the fighters one by one guide them in what they had to do. (The Child borrows his uncle's gun, p.53)(

\subsubsection{Repetition of the same nouns after words}

The repetition of the same nouns after words is used to assert and strengthen the meaning.

The translator should translate the repeated words literally as in example (8). Therefore, the translations of examples ( $6 \&$ \%) would be better as follows: Legally, you know: a piaster by piaster. In example (7); the words bastard is not appropriate; the word villain should be used instead. It should be repeated three times as follow:

The villain was challenging him. The villain was testing him, the villain was having his revenge.

): حلالي، أنت تعرف: قرش فوق قرش. (الصغير يستعير مرثنية خاله ويشرق الى صفد،ص20)6مثال (

TT: Legally, you know, every single piastre. (The Child borrows his uncle's gun, p.50)

مثال (7): الو غد يتحداه. الو غد يمتحنه. الوغد ينتقم منه. (الحر افيش، ص291)

Arab World English Journal for Translation \& Literary Studies 
TT: The bastard was challenging him, putting him to the test, having his revenge. (The Harafish, p.194)

$$
\text { مثال (8): الفقر يا ابن العم الفقر. (البنادق في المخيم،ص335) }
$$

TT: The poor, cousin . . the poor. (p.132, Guns in the camp)

\subsection{Verb Repetition}

The verb is repeated to reinforce the action and no need to repeat the subject. The translator should use a strategy to express this emphasis regardless of kinds of the used verb by using literal translation or adding words to reinforce the intended meaning. Therefore, the translator translates the repeated imperative verbs literally in examples ( $9 \& 10)$, which expresses the intended emphasis. The verbs (جئت، انكسر) are repeated to assert the meaning of coming and feeling crushed consequently in examples $(11 \& 12)$. The repetition is dropped which means that the translator opts for omission as a translation strategy to render the verbal repetition in the ST. This caused the English sentence to lose its forceful effect and subsequently its emphatic connotation that is indicated by the repetition of the original (انكسر، جئت). Therefore, the translator should provide literal translation or use verbs to do to express the intended emphasis as follow:

I remembered the festival because you were late so I did come and just on time.

Suddenly he felt so crushed, so crushed by a sense of a total loss.

مثنال (9): اخرجو ا ، اخرجو إدون تردد. (او لاد حارتنا، ص1261) (121)

TT: Get out! Get out at once! (p.81)

مثال (10): و اصبر اصبر حتى تعود نور . (اللص و الكلاب، ص75ack.

TT: Just keep cool, keep patient, until Nur comes back. (The thief and the dogs, p.41)

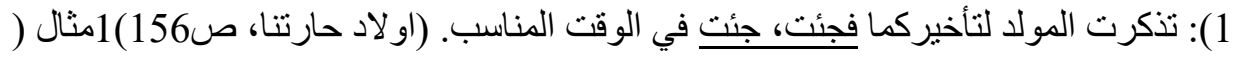

TT: I remembered the festival because you were late so I came and just on time. (p.100)

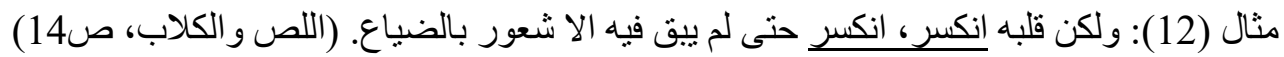

TT: suddenly, he felt crushed by a sense of total loss. (The thief and the dogs, p.10)

\subsection{Particle Repetition}

The repetition of particles, whether it is for answering or not, is for emphasis. It resembles the speaker's reaction i.e., it reflects the speaker's impatience or irritation to assert his/her point. The translator should repeat the particle to keep its emphatic function as in example 13 and 15. The translation would be better, in example 14 if the translator repeats the particle "no" twice as in TT.

مثال(13): كلا،كلا، لم ينسحب. (الصغير و ابوم و المرتينه، ص92)

TT: No, no, he didn't retreat. (the child, his father, and the gun go to the citadel, p.96) 
مثال (14): لا.لا اريد الذهاب الى حيفا.(عائد الى حيفا،ص359)

TT: No, I don't want to go to Haifa. (Returning to Haifa, p.159)

$$
\text { مثال (15): ولكن ابدا ابدا لم اتصور انها ستفتح من الناحية الاخرى. (عائد الى حيفا، }
$$

TT: But I never, never imagined that it would be opened from the other side. (returning to Haifa, p.150)

\subsection{Sentence, phrase or clause repetition \\ 1.4.1 Nominal sentence}

In the following example, the speaker admits that his girlfriend Noor is very kind, so he does love her. Repetition here is used to express an evident love feeling i.e. to declare the speaker's feeling or point of view to pay the listener attention. The translator ignores the repetition of the nominal sentence by paraphrasing the semantic connotation. Therefore. The translator fails to render the message in TLT, so the intended meaning is ignored. The translation would be better as follows: You are so kind, so kind to me Noor. I want to admit that to you.

مثال(16): انت طيبة جدا، انت طيبة جدا يا نور. أحب أن اعترف بذلك. (اللص و الكلاب، ص116)

TT: You are really very good to me. I want you to know I admit you grateful. (The Thief and The Dogs, p.128)

\subsubsection{Repetition the same nominal sentence after words}

The repetition here is used to assert the idea or for persuading purposes, so the translator should repeat the same sentence to reinforce what the speaker wants. As what the translator does in example 17 by repeating the same nominal sentence after words, but he should use the same subject of the sentence so it would be better as follows: This child loves the fields . . . the child loves the fields.

$$
\text { مثال(17): هذا الصغير يحب الحقول. . . الصغير يحب الحقول. (الصغير يستعير مرنينة خاله، ص29) }
$$

TT: The little one loves the fields ... the child loves the fields. (The Child borrows his uncle's gun, p.56)

\subsubsection{Verbal sentence}

The repetition here is also used to assert the speaker's idea to persuade the listener about the speaker's idea. The following examples $(18 \& 19)$ repeats the verbal sentences to reinforce the idea. The translation in 18 is suitable by repeating the sentence as in TT to assert the intended meaning, but in 19 the translator ignores the repeated sentence and depends on semantic connotation. Therefore, the translator omits the emphasis in the sentence, and that is what the writer wants so the translation would be better as follow: He was on the brink of madness . . he was on the brink of madness, but refused to despise his mother. 
مثال(18): لست أدري، لست ادري، أنا لم أسأله، كما تعرف وهو لم يقل. ( الصغير وابوه والمرتينة يذهبون الى قلعة جدين، (76)

TT: I don't know, I don't know. I didn't ask him, and he didn't say. (the child, his father, and the gun go to the Citadel, p.87)

مثنال(19): انه يعانق الجنون ـ .يعانق الجنون ويرفض أن يحتقر أمه. (الحر افيش، ص 131)

TT: He was on the brink of madness but refused to despise his mother. (The Harafish, p.87)

\subsection{Pronoun repetition}

The three examples below represent the repetition of the same independent pronoun in each example (انت، هم). The speakers address the listeners in the example whether to praise them or curse them in different ways. Therefore, the speaker repeats the independent pronouns, probably with intonation to emphasize the fact. The translator of 20 repeats the independent pronoun to keep the emphasis function. The translator of $21 \& 22$ does not repeat the pronouns (ه) and (انت) consequently, thus the sentence loses its emphatic source. The emphatic function is appeared in ST by repeating the pronouns, so the TTs are not forceful as the original as a result of ignoring the emphatic function. The speaker in $21 \& 22$ uses the definite Arabic article (al-) to specify his sons in 21 and his counterpart in 22. Better translations would be:

You, you are the rabble.

You, you are filthy.

مثال(20): انت انت سر سعادتنا. (او لاد حارتنا، ص268)

TT: It's you; you're the secret of our happiness. (the children of Gebalawi, p.173)

مثال(21): هم . . هم الأوباش. (الحر افيش،ص36)

TT: My sons are the rabble. (The Harafish, 21)

): انت انت القذر. (الحر افيش،ص298) مثال(22)

TT: You ought to talk! Filthy son of a bitch. (The Hrafish, p.198)

\subsubsection{Attached pronoun with independent one}

The use of independent pronoun (نحن) to emphasize the attached pronoun (بيتنا) in example 23 and the independent pronoun (انت) to emphasize the attached pronoun (اليك) 24. The independent pronouns in the two mentioned examples are used to assert and reinforce the idea the speaker when they talk to the addressee. The speaker, in example 23 wants to emphasize that the house is theirs and in example 24 the speaker wants also to emphasize that he resorts to her. Therefore, the translation would be better as follows in 23 and 24 consequently:

I mean, your presence here, in this house, our house . . ours . . Safiyya's and my house. 
That's why I resort to you . . you

مثال(23): اقصد ان وجودك هنا. في هذا البيت، بيتنا نحن، بيتنا اناوصفية. عائد الى حيفا،ص368)

TT: I mean, your presence here, in this house, our house, Safiyya's and my house, (returning to Haifa, p.164)

مثال(24) : لذلك لجأت اليك انت! (اللص و الكلاب، ص70)

TT: That's why I came to you instead of anybody else.

\subsection{Adjective Repetition}

The repetition of the same adjectives in the following examples (25 \& 26) seems to emphasize the speaker's intended idea. The speaker wants to assert that the door opened all the time in 25 and to emphasize that Abu Saad is really crushed in 26 so he repeated the adjective to show to what extent he is crushed. So, the translation or repeated adjectives should be translated as in 26 because it is deliberate. The translation in 25 would be better: at the opened door, open all the time.

$$
\text { مثال(25): أمام الباب المفتوح، المفتوح دائما. (ابو الحسن يقوص على سبارة انكليزية،ص58) }
$$

TT: At the door which was, as always, open. (Abu Al-Hassan ambushes an English car, p.76)

مثال(326): كان أبو سعد مدعوسا، مدعوسا بالفقر ومدعوسا بالمقاهرة ومدعوسا بكرت الاعاثة ومدعوسا تحت سقف الزينكو

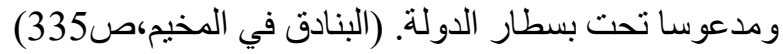

TT: Abu Saad had been crushed. Crushed by the poor, crushed by the victors, crushed by the ration card, crushed under a tin roof. Crushed under the domination of the country. (Guns in the camp, p.132).

\subsection{Adverb Repetition}

The examples below describe the situation of action exactly or a habit. Therefore, the adverbs are repeated to indicate the action exactly which are difficult to omit. The translators in $27 \& 28$ look unaware of the function of repeated adverbs, so they ignored them in the translations. Though they translate with good grammatical sentences, but they do not express the emphatic function indicated by Arabic sentences i.e. omission does not serve the function. Translations would be better:

Zaynab was always, always ahead of him.

Watching his father dying slowly, slowly without any single movement.

The translator keeps the emphatic function by repeating the adverb as in 29 .

مثال(27): دائما دائما تتقدمه زينب. (الحر افيش، ص22) 
TT: Zaynab was always ahead of him. (The Harafish, p.14)

مثال(28): وهو يرى أن أبيه يموت رويدا رويدا دون حركة واحدة. ( الصغير وابوهو المرتينة يذهبون الى قلعة جدين،ص95)

TT: Watching his father slowly dying, impotent and unmoving. (the child, his father, and the gun go to the Citadel, p.98)

مثال(29):و اعترف بينها وبين ذاته: ولكنها جاءت ببطء شديد ببطء شديد. (صديق سلمان يتعلم أشياء كثيرة في ليلة و احدة،123)

TT: He admitted to himself: “it's coming very slowly." "very slowly." (Suliman's friend learns many things, p.116)

\section{Repetition with synonyms}

Emphasizing a particular form by a synonymous word, phrase, or a sentence is very common in both Arabic and English discourses. Shunnaq (1989, p.43) states that this phenomenon is very natural in Arabic discourse while in English, it might be tautological.

\subsection{Noun repetition with its synonymous}

The speaker wants to emphasize the idea and eliminate any doubts, so the speaker uses the noun with its synonym to pay the listener attention and to eliminate any doubts for the listener too. Therefore, the translator opts literal translation in example (30) which keeps the emphatic function, but the translator paraphrases the meaning of the word and its synonym as "never been" in example (31) ignoring the emphatic role by omitting them. It would be better if the word and its synonym were rendered literally as in:

I've never worked as a porter a single hour in my life.

مثال(30): لا تتحرك خطوة واحدة. (الصغير و ابوه و المرتينه،ص92)

TT: Don't move a single step. (the child, his father, and the gun go to the citadel, p.96)

مثال(31): لم اشتخل حمالاً ساعة و احدة في حياتي. (الحر افيش، ص17)

TT: I've never been a porter in my life. (the Harafish, p.7)

\subsection{Adjective repetition with its synonymous}

The use of the adjective and its synonymous to emphasize the idea and make it more expressive, emotive and communicative. The words (براق ، لامع) in 32 are synonymous, indicating that the speaker describes the students' way of focus and admiration. However, the translator paraphrases the shared meaning of the two words ignoring the emphatic function by using both synonyms (bright, gleaming) together in the same context. It would be better if the two synonyms are rendered literally as in:

Arab World English Journal for Translation \& Literary Studies 
the pupils clapped when the child returned to his seat, where he sat quietly. Sixty staring eyes, bright and gleaming, but Muhsin

The translator is aware of emphatic function in 33, so the adjective and its synonymous are used in the translation (anguish, desperation) to keep its expressive and emotive roles.

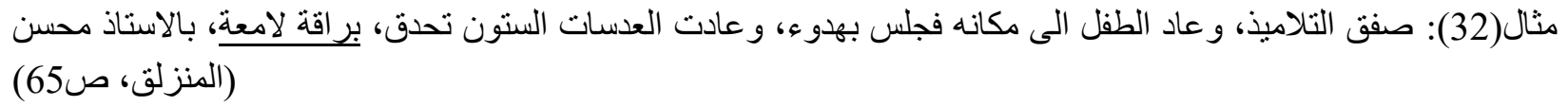

TT: The pupils clapped when the child returned to his seat, where he sat quietly. Sixty staring eyes, a twinkle, but Muhsin. (The Slope, p.34)

(ورقة من الرملة، ص46) مثال(33): وارتفعت من هنا و هنالك بعض الاحتجاجات اليائسة البائسة.

TT: and from here and there cries of anguish and desperation arose. (Paper from Ramleh, p.38)

\subsection{Verb repetition with its synonymous}

The use of a verb and its synonym is to reinforce the intended meaning and to assert the connotation emphasis. Therefore, the translator opts literal translation as in examples $(34,35,36)$. The translation for the underlined words would be better as follow: abusing and cursing, rant and rage, threating and swearing consequently.

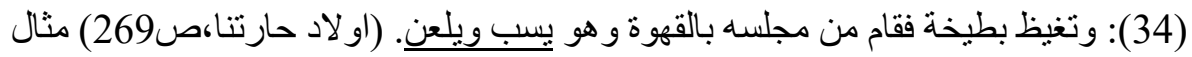

TT: Batikha was annoyed and get up from his place in the café, cursing and swearing. (p.174)

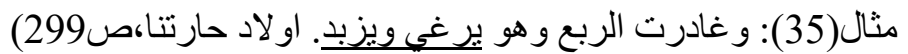

TT: He talked out fuming with rage. (p.194)

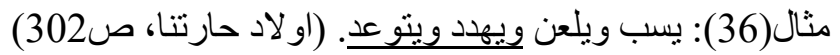

TT: cursing and swearing and uttering threats. (p.196)

\section{Conclusion}

This study concludes that to some extent, there is some kind of formal-functional correspondence of particular Arabic and English emphatic structures and devices, but not all. In other words, there are some symmetries and asymmetries in this regard. Regarding symmetries, there are several Arabic emphatic structures and devices which have equivalents in English such as synonyms and verbal repetition. Regarding asymmetries, there are several Arabic emphatic devices, and structures which are untranslatable into English; they have no parallel equivalents in English. Among these are the pronouns and emphatic particles. To sum up, the translation process is an integrated one. It overlaps with several linguistic aspects: semantic, syntactic and pragmatic. Therefore, translating Arabic verbal emphatic structures into English would be affected by the syntactic, semantic and pragmatic symmetries and asymmetries between the two languages. 


\section{About the Authors:}

Haitham ALYousef is a PhD student in School of Languages, Literacies and Translation at Universiti Sains Malaysia. He is interested in teaching linguistic and translation courses. His research interests in interpreting, intercultural communication, language and culture. More specifically, his work examines linguistic aspects of translating humor. ORCID ID: https://orcid.org/0000-0002-7495-3563

Professor Dr. Tengku Sepora Tengku Mahadi is a teaching staff at MA Translation for Professional Department in School of Languages, Literacies and Translation. Universiti Sains Malaysia. She was the former dean for the school. Her research interests are in linguistics and translation fields. She has many researches in the fields. ORCID ID: http://orcid.org/0000-00033302-0078

\section{References}

ALAubaidi, N. H. (2013). A Rhetorical Study of Emphasis in English with reference to Arabic. ADAB AL-FARAHIDI, 15, 60-78.

Albayati, S. (2003) قواعد النحو العربي في ضوء نثريات النظم.6awaed alnahw alarabi fi dhoue nathariyyat alnudhum). Dar Wael for publishing: Amman, Jordan.

Al-Gharanawi, H. (2005). الخلاصة في النحو. (Alkhulasah fi alnahw). Dar Al-Wafae for publishing: Alexandria.

Alhrout, A. (1983). أسلوب التوكيد بين البمنى والمعنى (Osloub Altawkid bayn almabna wa alma'ana). Unpublished MA Thesis, Yarmouk university, Jordan.

Baker, M. (2018). In other words: A coursebook on translation. London: Routledge.

Celec-Murica, M. \& Larsen-Freeman, D. (1983). Grammar Book. NewBury House Publishers. INC: USA.

Deeb, E. (1984). اساليب التاككيد في اللغة العربية (Asaleeb al-ta'akeed fi allughati alarabiyya). Dar alfikr allibnani: Beirut.

Fathi, Y. H. (2004). Reinforcement by repetition in English and Arabic. ADAB AL-RAFIDAYN, 38, 23-46. Retrieved from http://search.mandumah.com/Record/660334.

Farghal, M. (1993). The Translation of Arabic Cognate Accusatives into English. Turjuman, 2, 77-92.

Frodesen, J. \& Eyring, J. (2000). Grammar Dimension: from meaning and use. $4^{\text {th }}$ edition Heinel $\&$ Henel, a division of Thomas learning Inc.

Gleason, H. A. (1966). Linguistics and English Grammar. New York: Holt, R nehart and Winston. Hassan, A. (2015). Translating Arabic Verb Repetition into English. Arab World English Journal, 6(2), 144-153. doi:10.24093/awej/vol6no2.11.

Johnston, B. (1991). Repetition in Arabic Discourse. John Benjamins: Amesterdam.

Kanafani, G. (2000). Palestine's Children: Returning to Haifan and Other Stories. London: Lyne Rienner.

Maghalisah, M. (1997). النحو الثافي (Alnahw alshafii). Dar alshrouq: Amman. 
Mafouz, N. (1961). The Thief and The Dogs. Maktabat Misr: Cairo.

Maḥfūz, N. (1988). Children of Gebelawi. Washington, D.C.: Three Continents Press.

Mahfouz, N. (2013). The Harafish. London: Transworld Digital.

Mcarther, T. (1992). The Oxford Companion to the English Language. Oxford University Press.

Mohammed, M. J. (2013). A study of Some Emphatic Arabic Particles in the Glorious Qur'an with Reference to Translation. College of Basic Education Researchers Journal, 3(1), 935-948. Retrieved from http://search.mandumah.com/Record/632179.

Nahr, H. (2004) التر اكيب اللغوية. (Altrakeeb allughaweyah). Alyazouri: Amman.

Quirk, R. \& Greenbaum, S. (1973). A Concise Grammar of Contemporary English. Seminar Press: New York.

Shunnaq, A. T. (1989). Repetition in Arabic With Special Reference to Political Discource (Unpublished doctoral dissertation). The Victoria University of Manchester.

Shunnaq, A. T. (1993). Lexical Incongruence in Arabic-English Translation due to Emotiveness in Arabic. Turjuman. 2(2): pp. 37-63. 